tion, the instruction of local labour, continuous control, and consultation. The Gladitz Company has already installed complete factories in many countries of the world, with departments for wire treating, glass treating, exhausting, and finishing the lamps. It is interesting to notice that several of these factories are now being controlled by the large lamp companies. The company considers that this is a com. pliment to the work turned out by the factories it has started. It is busy at present in developing practical manufacturing methods of making neon signs for manufacturing purposes.

\section{Precautions in Use of Electro-Medical Apparatus}

Serious accidents from the use of electro-medical apparatus have so far been few in number, but the risk is likely to increase in the future, owing to more extended use of such appliances and also to the tendency to make use of the standard alternating current of 230 volts. Industrial experience shows that serious shock is more likely to result from alternating than from direct currents of the same voltage. The Ministry of Health has therefore issued a Memorandum (Mem. 161 Med.) with covering Circular (No. 1267) directing attention to precautions that ought to be taken in the use of electro-medical appliances, adoption of which should go far to minimise the risks involved.

\section{Researches from the University of Sydney}

The published work of members of the University of Sydney is made more generally available by the issue of collected reprints, which are now classified in twelve series, according to the nature of the research. We have recently received vol. 1, Reprints Nos. 18-24, in Series I. (Agricultural and Veterinary Science), vol. 1, Reprints Nos. 22-32, in Series VIII. (Medical Sciences-Clinical), and vol. 3, Reprints Nos. 1-19, in Series IX. (Medical Sciences-Non-Clinical). Most of the papers have been published within the last two years; a few are of less recent date. Most, but not all, were originally published in Australian journals. The range of subjects dealt with in each volume is wide, and indicates that an active spirit of research animates Australian scientific workers.

\section{Hawaiian Volcano Observatory}

WE regret to learn that, from July 1, the annual fund allotted to volcanology through the U.S. Geological Survey has been reduced from 35,000 to 15,000 dollars. Most of this sum is required for the work of the Hawaiian Volcano Observatory, and one of the first results of the reduction is that the weekly Volcano Letter, first issued in 1925 , is to be replaced by a monthly leaflet. There will be no suspension of the research work, though the staffs at all the stations, n Hawaii, California, and Alaska, will be reduced.

\section{Announcements}

THE fifteenth Faraday Lecture of the Chemical Society will be delivered by Prof. P. Debye, of Leipzig, on March 29, 1933.

DR. H. R. MmI, who during his long association with the Royal Geographical Society has been actively engaged in the promotion and preparation of the polar expeditions of the past forty years or so, has been appointed by the King of Norway a Commander (2nd Class) of the Order of St. Olav, for his services to Norwegian arctic explorers. This order has previously beon conferred upon Sir Clements Markham, Sir Errnest Shackleton, and Sir John Seott Keltie.

Mrs. Bowen, Titcomb Manor, Kintbury, Berks, informs us that she has fifteen bound volumes of Nature, namely, vol. 45 to vol. 60 , extending from Nov. 1891 to Oct. 1899, with the exception of vol. 54, which she generously offers to present to a suitable college, institute, or scientific worker, in need of them, upon payment of carriage. Communications should be sent direct to Mrs. Bowen at the above address.

A special volume (vol. 9) of the Australian Journal of Experimental Biology and Medical Science has been issued as a memento of the late Prof. Brailsford Robertson, who founded the Journal and, until his death in January 1930, was its chief editor. The volume contains a biographical account of his scientific work, a bibliography of his writings, and nineteen papers specially contributed by his former colleagues and pupils, who are all acknowledged authorities on the subjects on which they write. The volume forms a unique and interesting collection of papers on those biochemical aspects of biological science to which the late Prof. Robertson during his lifetime made such notable contributions, both directly by his own individual work and indirectly by his inspiring influence on a wide circle of colleagues and pupils.

THE annual Report of the Governing Body of the Lister Institute of Preventive Medicine, recently issued, announces that Prof. William Bulloch has been elected chairman of the governing body, in succession to the late Sir David Bruce. An excellent survey of the numerous researches carried out by workers at the Institute is presented. The National Collection of Type Cultures, housed at the Institute, has had two hundred cultures added, and has distributed more than five thousand cultures, during the year.

AppricATrons are invited for the following appointments, on or before the dates mentioned:-An assistant lecturer in zoology at the University of Birmingham-The Secretary (July 17). A lecturer in electrical engineering and physics at the Borough Polytechnic, Borough Road, London, S.E.1-The Principal (July 18). A principal of the College, and a headmaster of the College Secondary School, Swindon-The Director of Education, Education Office, Clarence Street, Swindon (July 21). A principal of the new Technical School, Hong-Kong-The Secretary (SIR/CA), Board of Education, Whitehall, London, S.W.1, or, for Scottish applicants, The Secretary, Scottish Education Department, Whitehall, London, S.W.1 (July 23). A lecturer in zoology at University College, Nottingham-The Registrar (July 30). A demonstrator in biology at Guy's Hospital Medical School, London Bridge, S.E.l-The Dean (Aug. 5).

No. 3272 , VoL. 130] 